\title{
ステンレス鋼の高温酸化挙動に対する $\mathrm{LaCrO}_{3}$ 被覆の効果*
}

\author{
金野 英 隆**, 北崎 聡**, 古市隆三郎** \\ ** 北海道大学工学部
}

\begin{abstract}
Effect of $\mathrm{LaCrO}_{3}$ Coating on the High Temperature Oxidation of Stainless Steels*
\end{abstract}

\author{
Hidetaka Konno**, Satoru Kitazaki**, and Ryusaburo Furuichi** \\ ** Faculty of Engineering, Hokkaido University
}

\begin{abstract}
Formation conditions for lanthanum chromium oxide, $\mathrm{LaCrO}_{3}$, coating on SUS 304 and 430 stainless steels were determined and the effects of the coating on high temperature oxidation of the steels were examined. The coated steels showed excellent oxidation resistance at $1273 \mathrm{~K}$ in $0.20 \mathrm{~atm} \mathrm{H}_{2} \mathrm{O}$-air and under cyclic oxidation in air $(20 \mathrm{~h}$ at $1173 \mathrm{~K} / 4 \mathrm{~h}$ at room temperature). After the oxidation tests, small amounts of $\mathrm{Cr}_{2} \mathrm{O}_{3}$ and $(\mathrm{Mn}, \mathrm{Fe})(\mathrm{Fe}, \mathrm{Cr})_{2} \mathrm{O}_{4}$ spinels were found under the coating but not on the coating, and the $\mathrm{Cr}_{2} \mathrm{O}_{3} /$ spinel ratio (by XRD) was smaller than with the uncoated steels oxidized under similar conditions. Voids due to internal oxidation were also found in the outermost part of the coated steels. These findings suggest that the coating functions as a barrier preventing metal ions from migrating outward, resulting in a low oxidation rate.
\end{abstract}

Key words: electrodeposition, high temperature oxidation, lanthanum chromium oxide, oxide coating, rare earths, stainless steel

\section{1. 緒言}

クロムを含む鉄基あるいはニッケル基合金に希土類な どの活性元素を添加すると酸化性雾囲気にお打る高温耐 食性が著しく向上することは良く知られている。活性元 素の作用機構についてはまだ十分明らかになってはいな いが，主な効果は，均一な保護性の $\mathrm{Cr}_{2} \mathrm{O}_{3}$ 皮膜の生成を 促進し，乙かも一旦この皮膜が形成するとその後の皮膜 成長速度を遅くすること, 拈よび, $\mathrm{Cr}_{2} \mathrm{O}_{3}$ 皮膜の密着性 を著しく改善することである1”。添加法としては，バル クに加える方法と, 表面のみに活性元素を含む層を形成 する方法の二つに大別でき，多くの方法が提案されてい るが，経済性を考慮すると，バルクへの添加量はできる だけ減らし，化学的または電気化学的な手法による表面 改質と併用することが望ましいと考えられる。

以上の点から, 活性元素とクロムを含む複合酸化物皮

* 第36回腐食防食討論会（広島, 1989）にて発表

** $\bar{T} 060$ 札幌市北区北13条西 8 丁目 (N 13 W8, Kita$\mathrm{ku}$, Sapporo, 060 Japan)
膜で合金を被覆すれば耐高温酸化性を向上できると考 え, ステンレス鋼の表面に複合酸化物皮膜を形成する方 法を検討した結果, 電解クロメート処理法と類似の方法 により $\mathrm{Zr}-\mathrm{Cr}$ または $\mathrm{Ti}-\mathrm{Cr}$ 複合酸化物皮膜を形成でき ること ${ }^{2), 3)}$ および， La(III)-Cr(VI) 溶液から電析した皮 膜を熱分解することにより比較的低温でペロブスカイト 型の $\mathrm{LaCrO}_{3}$ 皮膜を形成できること文を見い出し，これ らによる被覆がステンレス鋼の耐酸化性の向上に, 有効 であることを報告した ${ }^{2) ~ 4) 。 ~}$

本研究に打いては, 高融点 $(2750 \mathrm{~K})^{5)}$ で電子伝導性 (ca. $4 \mathrm{~S} / \mathrm{m}$ at $1400 \mathrm{~K})^{5}$ ) を持ち, 化学的に安定な $\mathrm{LaCrO}_{3}$ 被覆によるステンレス鋼の耐酸化性の向上の程度を詳細 に検討するとともに，酸化挙動，特に酸化物/合金界面 がどのような影響を受けるかを調べた。

\section{2. 実験方法}

Table 1 に組成を示した試料（厚さ $1 \mathrm{~mm}$ ) を $20 \times 10$ または $20 \times 15$ (GDS にのみ使用) $\mathrm{mm}^{2}$ に切り出し, エ 
Table 1 Composition of stainless steels in mass $\%$.

\begin{tabular}{llccccccc}
\hline & $\mathrm{Fe}$ & $\mathrm{Cr}$ & $\mathrm{Ni}$ & $\mathrm{Mn}$ & $\mathrm{Si}$ & $\mathrm{C}$ & $\mathrm{P}$ & $\mathrm{S}$ \\
\hline SUS 304 & $\mathrm{Bal}$. & 18.37 & 8.32 & 0.99 & 0.62 & 0.06 & 0.027 & 0.011 \\
SUS 430 & $\mathrm{Bal}$. & 16.06 & 0.14 & 0.38 & 0.50 & 0.050 & 0.027 & 0.004
\end{tabular}

メリー紙で No. 500 まで湿式研磨したのち, アセトン中 で $20 \mathrm{~min}$ 超音波洗浄した。断面観察および分析用の試 料は必要に応じてNo. 1000 まで湿式研磨したのちダイ ヤモンドスラリーで鏡面に仕上げた。試料はすべてデシ ケーター中に一昼夜以上放置してから実験に用いた。

前処理した試料を，Pt を対極として $0.1 \mathrm{~mol} / \mathrm{dm}^{3}$ $\left(\mathrm{NH}_{4}\right)_{2} \mathrm{Cr}_{2} \mathrm{O}_{7}-0.1 \mathrm{~mol} / \mathrm{dm}^{3} \mathrm{La}\left(\mathrm{NO}_{3}\right)_{3}, \mathrm{pH}=2.3$ の 溶液 中, いろいろのカソード電位 $E_{c} / \mathrm{V}$ vs. SCE, で 6 min 分極し，ステンレス鋼の表面に電析皮膜を形成した。こ の電析皮膜は硝酸に可溶なので, ICP 発光分光法により 析出量および組成を分析し, $\mathrm{LaCrO}_{3}$ への前駆体として の化学量論組成 $\left([\mathrm{La}]_{f} /[\mathrm{Cr}]_{f}=1\right.$, 理想的には $\mathrm{LaOH}$ $\left.\left(\mathrm{CrO}_{4}\right)^{4)}\right)$ になっているかを調べた。この前駆体皮膜を 空気中で熱処理して $\mathrm{LaCrO}_{3}$ に転換した4)。

耐高温酸化性の評価は (a) 加速酸化試験：0.2 atm の 水蒸気を含む空気中, $1273 \mathrm{~K}$ または $1373 \mathrm{~K}$ で酸化増量 曲線 $(\Delta W-t)$ の測定, および (b) 繰返し酸化試験: 空気 中, $1173 \mathrm{~K} / 20 \mathrm{~h}$-室温 $/ 4 \mathrm{~h}$ のサイクルを繰り返し, 1 サ イクルごとに質量増加を測定，により行った。

高温酸化の前後に括ける, 皮膜および皮膜/合金界面の 構造や組成変化は, 光学㫫微鏡, SEM, XRD (30 kV-20 mA Cu K $\alpha$, monochromated detector), GDS (RSV ANALYMAT 2504, Ar 圧 $860 \mathrm{~Pa}$, 放電電压 $550 \mathrm{~V}$ (定 電圧パルス)によった。

\section{3. 実験結果および费察}

\section{1 ステンレス鋼上への $\mathrm{LaCrO}_{3}$ 被覆形成条件と被} 覆の性状

SUS 304 および SUS 430 鋼に電析した前駆体皮膜の 分析結果を Table 2 に示す。上述の溶液执よび電解時間 では, いずれのステンレス鋼の場合も $-1.6 \mathrm{~V} て ゙[\mathrm{La}]_{f} /$ $[\mathrm{Cr}]_{f}$ モル比がほぼ 1 となり，析出量もほぼ同じである ことがわかった。この条件は, 必ずしも最適条件とは限

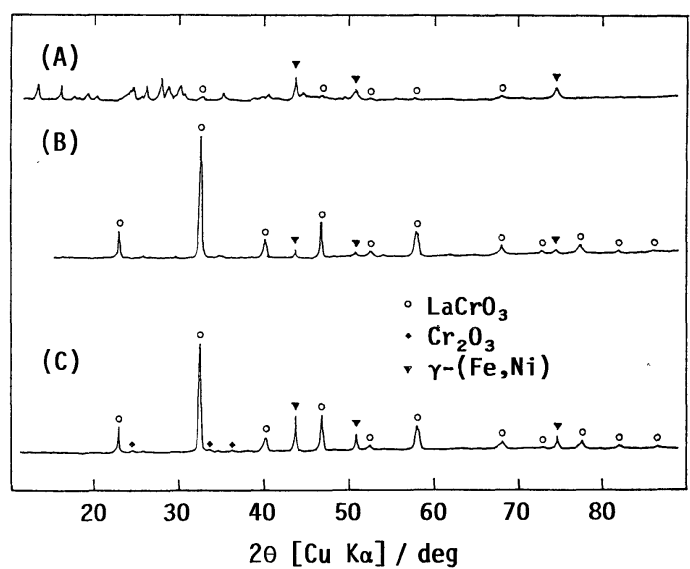

Fig. 1 XRD patterns of the SUS 304 stainless steel coated at $-1.6 \mathrm{~V}$ (SCE). (A) heat treaiment at $873 \mathrm{~K}$ for $10 \mathrm{~min}$, (B) sample (A) oxidized at $1273 \mathrm{~K}$ for $10 \mathrm{~h}$ in 0.20 atm $\mathrm{H}_{2} \mathrm{O}$-air, and $(\mathrm{C})$ heat treatment at $1073 \mathrm{~K}$ for $10 \mathrm{~min}$ (hereafter, " $\mathrm{LaCrO}_{3}$ coated" indicates this type).

らず, モル比, 析出量ともに溶液および電解条件によっ て変えられることは既て報告しだ)。モル比が 1 以下の 場合には, 熱分解によって被覆中に副生成物（扣もに $\left.\mathrm{Cr}_{2} \mathrm{O}_{3}\right)$ が含まれることになり, $\mathrm{LaCrO}_{3}$ の導電性が悪く なると推定されるが，耐食性の点では匡とんど違いがな かった(後述)。

電析した前駆体皮膜は，空気中， $923 \mathrm{~K} ， 60 \mathrm{~min}$ から $1073 \mathrm{~K}, 10 \mathrm{~min}$ 程度の熱処理で $\mathrm{LaCrO}_{3}$ に転換する4)。 しかし，ほとんど転換しないような低温短時間の熱処理 試料でも耐高温酸化性は事実上変らないことがわかった (後述)。これは, 上述の高温酸化試験の条件では, 試験 中（抢そらく最初期の極めて短時間のうち）に $\mathrm{LaCrO}_{3}$ への転換が起こり, 結果的に $\mathrm{LaCrO}_{3}$ 被覆を施したのと 同じになるためであり，このことは, Fig. 1 の酸化試験 前後の XRD の結果から確認できる。

電析物が完全に $\mathrm{LaCrO}_{3}$ 、に転換したとすると, -1.6 $\mathrm{V}$ での被覆量は打よそ $20 \mathrm{~g} / \mathrm{m}^{2}$ になる。これは, $\mathrm{LaCrO}_{3}$ の理論密度 $\left(6770 \mathrm{~kg} / \mathrm{m}^{3}\right)^{5)}$ から厚さ $3 \mu \mathrm{m}$ に相当するが, 熱処理によって生成した被覆の表面 (Fig. 2 (A) 中の入

Table 2 Composition of electrodeposited films.

\begin{tabular}{|c|c|c|c|c|}
\hline $\mathrm{E}_{\mathrm{c}}$ & \multicolumn{2}{|c|}{ SUS 304} & \multicolumn{2}{|c|}{ SUS 430} \\
\hline V vs. SCE & {$[\mathrm{Cr}]_{\mathrm{f}} / \mathrm{mmo} \mathrm{m}^{-2}$} & ${ }^{2[\mathrm{La}]_{\mathrm{f}} /[\mathrm{Cr}]_{\mathrm{f}}}$ & {$[\mathrm{Cr}]_{\mathrm{f}} / \mathrm{mmol} \mathrm{m}^{-2}$} & {$[\mathrm{La}]_{\mathrm{f}} /[\mathrm{Cr}]_{\mathrm{f}}$} \\
\hline-1.5 & $60.8 \pm 3.0$ & $0.88 \pm 0.02$ & $86.6 \pm 13.9$ & $0.86 \pm 0.01_{4}$ \\
\hline-1.6 & $89.8 \pm 8.0$ & $0.97 \pm 0.045$ & $93.2 \pm 12.5$ & $0.97 \pm 0.01_{4}$ \\
\hline-1.7 & $93.3 \pm 13.7$ & $0.92 \pm 0.01_{3}$ & $107.9 \pm 2.2$ & $0.96 \pm 0.02_{1}$ \\
\hline
\end{tabular}


(A)

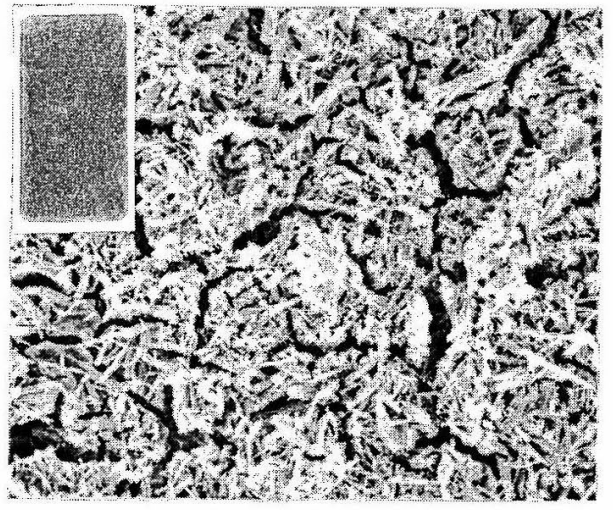

(B)
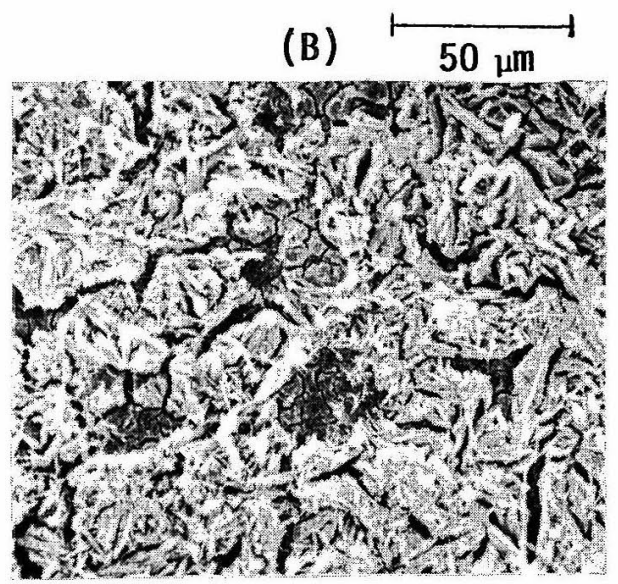

Fig. 2 Scanning electron micrographs of the $\mathrm{LaCrO}_{3}$ coated SUS 304 stainless steel. (A) as coated (the upper left is an appearance), and (B) after the oxidation at $1273 \mathrm{~K}$ for $10 \mathrm{~h}$ in $0.20 \mathrm{~atm} \mathrm{H}_{2} \mathrm{O}$-air.

込み写真) は粉吹き状であり, SEM 写真 (Fig. 2 (A)) では，表面は針状の結晶に覆われていて，一様でなくひ び割れのよらな部分も観察される。従って, 多孔度を考 虑に入れるとこれよりかなり大さな值になるすのと考觉 られる。表面の針状結晶は，容易にこすり取れるが，そ の下には比較的密着性の良い薄い皮膜が存在しており， このため表面層をこすり落としても酎酸化性の低下はあ まり見られなかった。

\section{$3.2 \mathrm{LaCrO}_{3}$ 被覆による耐高温酸化性の向上}

$\mathrm{LaCrO}_{3}$ の被覆を施した試料の $1273 \mathrm{~K}$ に挌ける加速 酸化試験の結果の一例を Fig. 3 に示与。SUS 304, 430 鋼のいずれについても, 被覆のない試料 (Blank) は短時 間の内に breakaway 酸化が始まる(この酸化条件での 平均寿命は, SUS 304 鋼で 33 min, SUS 430 鋼では 76 $\min )^{6)}$ が, 被覆した試料は長時間加速酸化が起こらず被 覆によって酎酸化性が著しく向上していることがわか

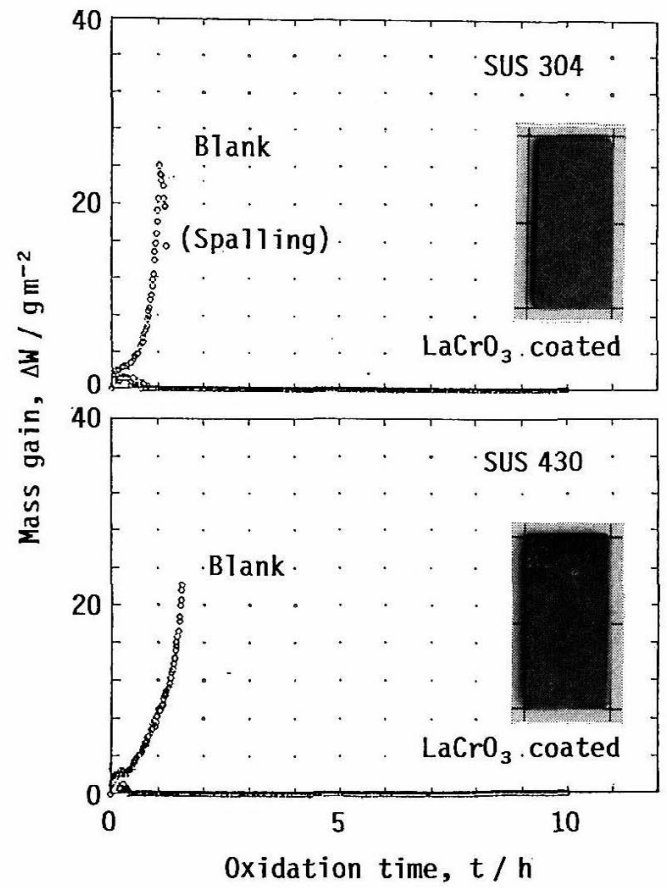

Fig. 3 The $\Delta W-t$ curves measured at $1273 \mathrm{~K}$ in $0.20 \mathrm{~atm} \mathrm{H}_{2} \mathrm{O}$-air. Here, the specimens coated with $\mathrm{LaCrO}_{3}$ are the same type with (A) in Fig. 1. Photographs show the surface of coated specimens after $10 \mathrm{~h}$ oxidation.

る。Fig. 3 の結果は $600 \mathrm{~min}$ で試験を打ら切ったもので あるが，図中の写真のよりに外観にはまったく変化が見 られなかった。被覆したSUS 304 鋼の $600 \mathrm{~min}$ 酸化後 の SEM 写真 (Fig. 2 (B)) では, 表面の針状結晶が脱落 したよらに見觉る部分がわずかにあるが，全体としては 酸化前の表面とほとんど変わっておらず， $\mathrm{LaCrO}_{3}$ が安 定で下地の合金の酸化を抑えている。

Table 2 の 3 条件で形成した皮膜を $873 \mathrm{~K}$ または $1073 \mathrm{~K} て ゙ 10 \mathrm{~min}$ 熱処理し, 同様の試験を行った結果, いずれも $600 \mathrm{~min}$ まで加速酸化は起きなかった。従っ て, $\mathrm{LaCrO}_{3}$ 単相の被覆でなくても耐高温酸化性はじゅ らぶん向上するといえる。

$\mathrm{LaCrO}_{3}$ 被覆（－1.6 V の皮膜を，1073 Kで $10 \mathrm{~min}$ 熱 処理）した 20 枚の SUS 304 鋼試料を加速酸化試験し た結果は以下の通りであった。な拉，breakawayなでの 寿命の決めかたは能報りによった。

$1273 \mathrm{~K}$ : No breakaway 9 枚 (600 min 打切) 1 枚 (1440 min 打切) Breakaway 3 枚 $(1040,1140,1140 \mathrm{~min})$

$1373 \mathrm{~K}$ : No breakaway 3 枚 (240 min 打切) 1 枚 (420 min 打切) Breakaway 3 枚 $(385,501,742 \mathrm{~min})$ 


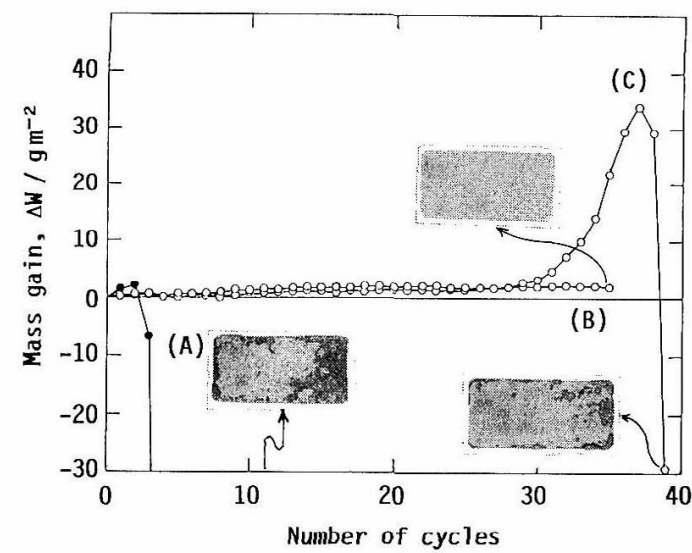

Fig. 4 Cyclic oxidation of SUS 304 stainless steel in an ambient atmosphere $\left(20 \mathrm{~h}\right.$ at $900^{\circ} \mathrm{C} /$ $4 \mathrm{~h}$ at room temperature). (A) blank, (B) and (C) $\mathrm{LaCrO}_{3}$ coated.

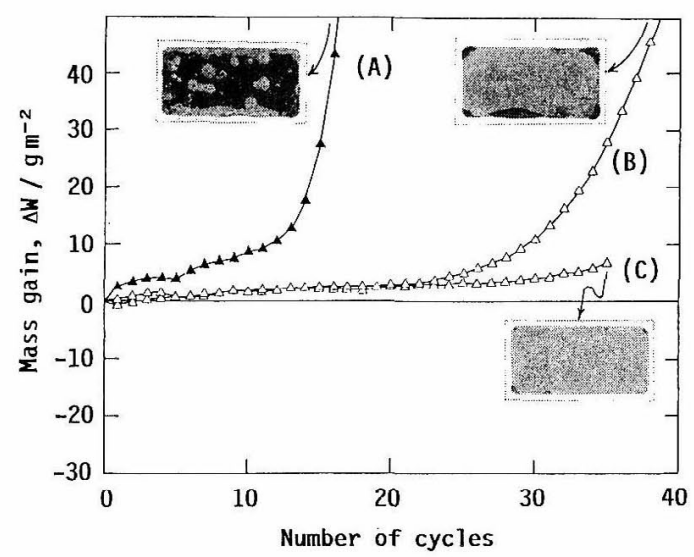

Fig. 5 Cyclic oxidation of SUS 430 stainless steel in an ambient atmosphere $\left(20 \mathrm{~h}\right.$ at $900^{\circ} \mathrm{C} /$ $4 \mathrm{~h}$ at room temperature). (A) blank, (B) and (C) $\mathrm{LaCrO}_{3}$ coated.

$\Delta W-t$ 曲線に breakaway を起こした試料はいずれりエ ッジに酸化物が形成してところどころ被覆が脱落してい たが, 面の部分には異常がなく, blank 試料に加速酸化 がおきた場合の表面”とはまったく異なっていた。主に エッジから速い酸化が始皂るといら点は次の繰返し酸化 試験でも同様であった。従って, $\mathrm{LaCrO}_{8}$ を被覆した試 料の $\Delta W-t$ 曲線に見られる breakaway はェッジ酸化 によるもので全面的な加速酸化による本質的なものでは ないといえる。

繰返し酸化試験の結果を Fig. 4 拉よび 5 に示した。 SUS 304 鋼の blank 試料は冷却巾に酸化皮膜の spalling が起こり 3 サイクルで $\Delta W$ が負になる (Fig. 4 (A), 写真は 12 サイクル後) が, 被覆すると 35 サイクルまで $\Delta W$ の増加が抑えられ，外観にも異常はない(Fig. 4 (B))。
試料によっては 30 サイクル付近から $\Delta W$ が増加し, 最 終的に spalling る起こすものもあった (Fig. 4 (C))。 SUS 430 鋼では酸化皮膜の spalling が起こらず，blank の寿命は SUS 304 鋼上り長い(Fig. 5 (A)) が, $\Delta W$ の 推移を見ると, 被覆の效果は SUS 304 鋼の方が大きい ように見える (Fig. 5 (B)，(C))。またいずれの鋼種です 被覆した場合，酸化が起こるのはエッジである (Fig. 4 (C) 扎よび Fig. 5 (B), (C)) が，これは，エッジルは被 覆が均一につきにくいことと, 熱応力がかかかりやすい部 分であるためと考觉らる。

\section{3 酸化物/合金界面の構造と組成}

Blank 扝よび被覆試料について, breakaway が起こ らない (Fig. 3 に例示した $\Delta W-t$ 曲線の立ち上がらな い）定常酸化が進行している色々な時点で酸化を止め, XRD 測定を行った結果の一部を Figs. 6, 7 に示す。合 金上に生成する酸化物からの回折強度が微弱なため, 酸 化後の被覆試料の測定の際には外側の $\mathrm{LaCrO}_{3}$ 被覆を こすり落としてから, エタノール中で $10 \mathrm{~min}$ 超音波洗

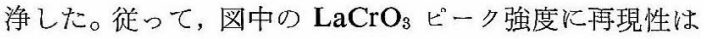
ない。被覆試料からの酸化生成物の回折強度は $\mathrm{LaCrO}_{3}$ 被覆をこすり落としても非常に小さいが，いずれの鋼種 でも生成する酸化物は $\mathrm{Cr}_{2} \mathrm{O}_{3}$ そスピネル（組成恃特し

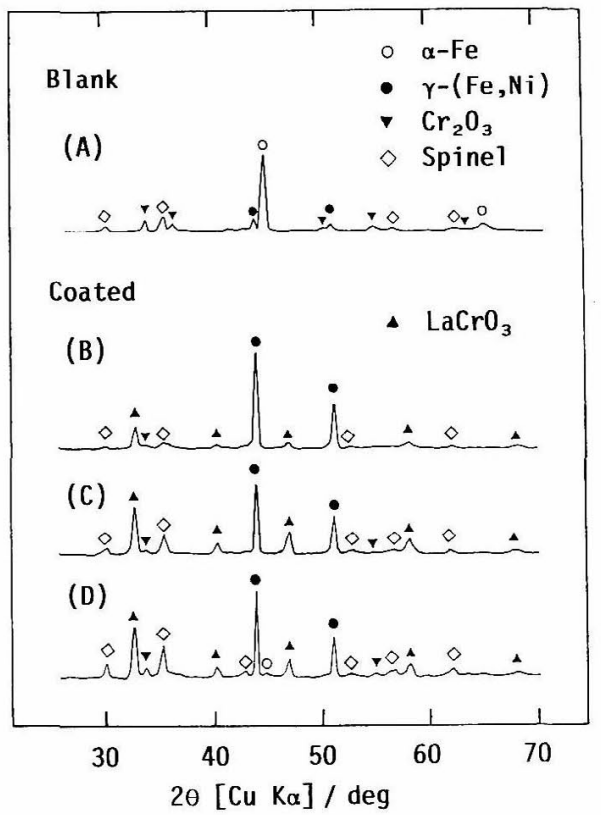

Fig. 6 XRD patterns of the SUS 304 stainless steel after the oxidation at $1273 \mathrm{~K}$ for (A) 30, (B) 30, (C) 240, and (D) $600 \mathrm{~min}$ in $0.20 \mathrm{~atm} \mathrm{H}_{2} \mathrm{O}$-air. Coatings were removed as much as possible before the measurements to enhance the intensities from oxides formed under the coatings. 


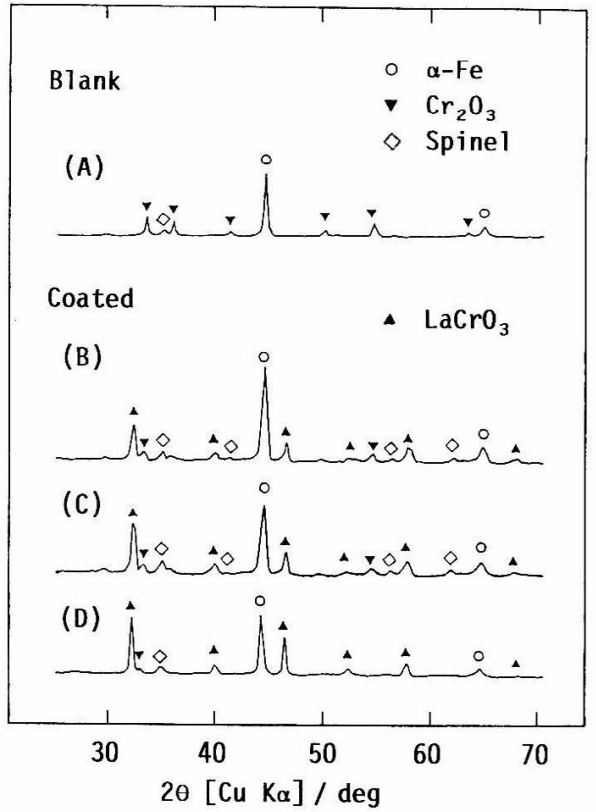

Fig. 7 XRD patterns of the SUS 430 stainless steel after the oxidation at $1273 \mathrm{~K}$ for (A) 60 , (B) 60, (C) 120 , and (D) $240 \mathrm{~min}$ in $0.20 \mathrm{~atm} \mathrm{H}_{2} \mathrm{O}$-air. Coatings were removed as much as possible before the measurements to enhance the intensities from oxides formed under the coatings.

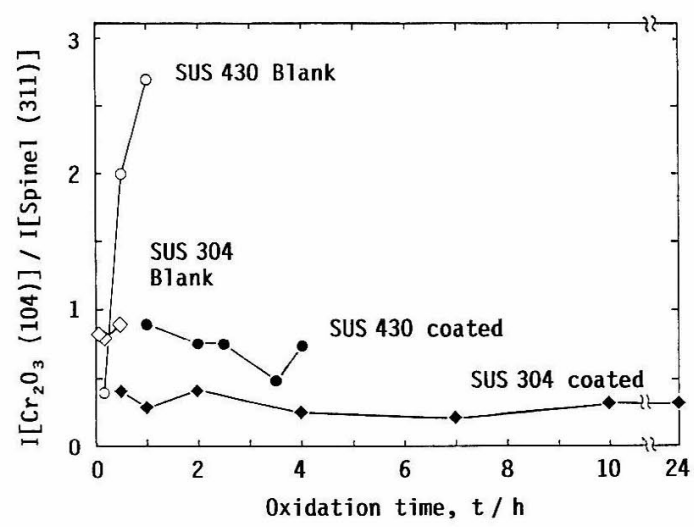

Fig. 8 The relative intensities of XRD peaks, $\mathrm{I}\left[\mathrm{Cr}_{2} \mathrm{O}_{3}(104)\right] / \mathrm{I}[$ Spinel(311)], after the oxidation at $1273 \mathrm{~K}$ for different periods in $0.20 \mathrm{~atm} \mathrm{H}_{2} \mathrm{O}$-air.

がたいが ( $\mathrm{Mn}, \mathrm{Fe})(\mathrm{Fe}, \mathrm{Cr})_{2} \mathrm{O}_{4}$ と推定) であり, blank と同じであった。しかし，相刘強度は著しく異なり，被 覆によって, $\mathrm{Cr}_{2} \mathrm{O}_{3}$ の相対強度が低下した。回折ピーク が最も強く，また隣り合っている $\mathrm{Cr}_{2} \mathrm{O}_{3}$ の (104) [2 $[2=$ $\left.33.6^{\circ}\right]$ とスピネルの (311) [2 $\left[2 \fallingdotseq 35.3^{\circ}\right]$ ピーク強度比を酸 化時間に対してプロットすると Fig. 8 のよらになる。
SUS 304

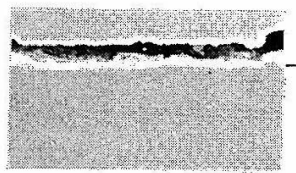

(B)

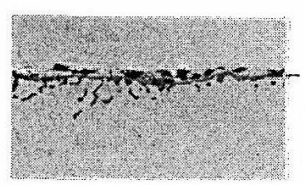

SUS 430

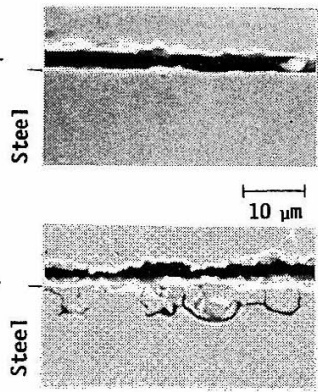

Fig. 9 Scanning electron micrographs of the cross-section of $\mathrm{LaCrO}_{3}$ coated stainless steel (A) before and (B) after the oxidation at $1273 \mathrm{~K}$ for $10 \mathrm{~h}$ in $0.20 \mathrm{~atm} \mathrm{H}_{2} \mathrm{O}-$ air.

Blank のデータはいずれも 1 時間以内しか無いが, Fig. 3 に示したよらに，これ以後は breakaway 酸化がおこ り， $\mathrm{Fe}_{3} \mathrm{O}_{4}$ 括よ゙ $\mathrm{FeCr}_{2} \mathrm{O}_{4}$ からなる厚いスケールが生 成する7ので比較の対象にならない。SUS 304 鋼では $\mathrm{Cr}_{2} \mathrm{O}_{3}$ の強度が被覆によって半分以下になり, たた, SUS 430 鋼でい最初期を除いて強度が逆転していることがわ かる。いずれも, 強度比は酸化時閒によってほとんど変 化しない。このよらな $\mathrm{Fe}^{2+}$ を含さスピネルの相対強度 の増大は, 合金近傍の酸素ポテンシャルが被覆によって 低下したことを示唆するものと考えられる。

被覆した SUS 304 および 430 鋼の酸化前および $10 \mathrm{~h}$ 加速酸化試験後の断面 SEM 写真を Fig. 9 に示す。酸 化後の合金界面にはボイドが生成しておう, 明らかに内 部酸化が起さていることを示している。これは SUS 304 鋼よりる SUS 430 鋼で著しく, ボイドが互いに横方向 につながっているのが見られ西。このように, 内部酸化 によって少量ではあるが(扣そらく粒界から) Cr が抜子 て酸化されているにもかかわらず，エッジがやられない 限り酸化による $\Delta W$ の増加は極めて小さい (SUS 304 鋼 の場合, $24 \mathrm{~h}$ 加速酸化試験後で $0.5 \mathrm{~g} / \mathrm{m}^{2}$ 以下)。 $\mathrm{LaCrO}_{3}$ は本実験の酸化条件では安定であり, 分解することは考 总られないので, 定量的な関係は把握できないが，生成 した $\mathrm{Cr}_{2} \mathrm{O}_{3}$ の一部が $\mathrm{CrO}_{2}(\mathrm{OH})^{8}, \mathrm{CrO}_{2}(\mathrm{OH})_{2}$ などの形 で蒸発することが， $\Delta W$ があまり変化しない理由の一つ になっているのではないかと推祭される。水蒸気を含む 雾囲気ではこのような化学種の形成による Cr の蒸発が

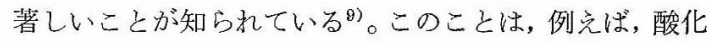
中に生成した被覆の割れ目のような部分を $\mathrm{Cr}_{2} \mathrm{O}_{3}$ が補 修している可能性も示唆する。これは，以下に述べる GDSの結果とも矛盾しない。

被覆した SUS 304 鋼の酸化前後の GDS による深さ 


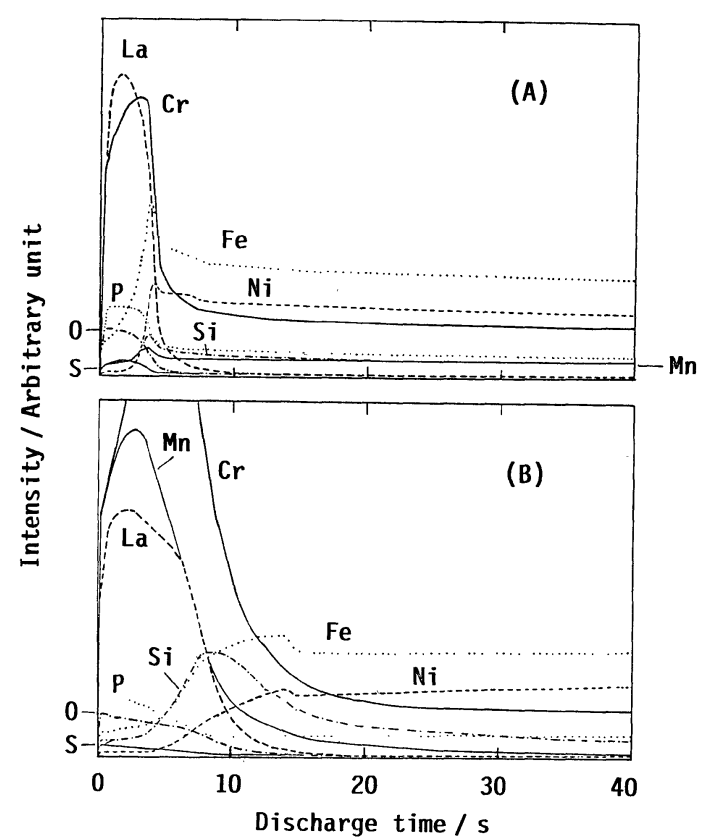

Fig. 10 Results of GDS analysis of the $\mathrm{LaCrO}_{3}$ coated SUS 304 stainless steel (A) before and (B) after the oxidation at $1273 \mathrm{~K}$ for $10 \mathrm{~h}$ in $0.20 \mathrm{~atm} \mathrm{H}_{2} \mathrm{O}$-air. Intensities are not proportional to concentrations.

方向の分析結果を Fig. 10 に示す。酸化物相と合金相の スパッター速度に著しい違いがあったため相対感度の補 正ができず，各元素の濃縮の程度などについて正確な考 察をすることはでさなかった。また, 測定に際して, 真 空度を保つため被覆の外側をこすり落としているので, $\mathrm{La}$ のプロファイルの幅は被覆相の厚さに対応してはい ない。以上の制約はあるものの，La プロファイルを基 準にすると, 酸化前と酸化後とでは明らかに被覆/合金 界面の金属イオンレベル, 特に, $\mathrm{Cr}, \mathrm{Mn}, \mathrm{Si}$ が変わって おり，酸化によって界面に新たな層が形成したことが分 かる。被覆層内に入り込んでいる成分もあるが, 被覆を 突き抜けて最表面に新たな酸化物が形成している形跡は ない。これは, Fig. 2 (B) に示した SEM 観察の結果か らも明らかである。被覆/合金界面側の C r および La の プロファイルが tailing を起こしているが, これは Fig. 9 に見られた内部酸化を反映するものと考学られる。

以上, 被覆層の外側での $\mathrm{Cr}_{2} \mathrm{O}_{3}$ などの酸化物形成がな く, 内部酸化が起こるといらことは, $\mathrm{LaCrO}_{3}$ 被覆が通 常生成する保護性の $\mathrm{Cr}_{2} \mathrm{O}_{3}$ 被膜に代って, 金属イオンの 外方拡散による酸化を妨げるバリアーとして働いている ことを示している。これらの結果からは, La イオンが 活性元素特有の役割1)を果たしている証拠はつかめなか ったが, $\mathrm{LaCrO}_{3}$ は $\mathrm{Cr}_{2} \mathrm{O}_{3}$ よりも熱的, 化学的に遙かに
安定であり，耐熱被覆として優れているといえる。

\section{4. 結 言}

$\mathrm{LaCrO}_{3}$ 被覆によるステンレス鋼の耐酸化性の向上な らびに被覆による酸化挙動（特に酸化物/合金界面）の变

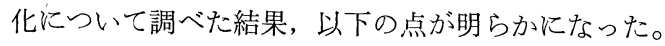

(1) 水蒸気/酸素雾囲気に护汗る加速酸化試験 お。 び大気開放下の繰返し酸化試験のいずれの場合にも, 被 覆によりステンレス鋼の耐酸化性が著しく向上すること が明らかとなった。

（2）被覆に上る耐酸化性の向上はSUS 304 鋼の方 がやや顕著である。

（3）加速酸化試験によって生成する酸化被膜は打も に $\mathrm{Cr}_{2} \mathrm{O}_{3}$ とスピネルからなり, XRD による $\mathrm{Cr}_{2} \mathrm{O}_{3} /$ ス ピネル相対強度は, 被覆試料の方が小さくなる。これは,

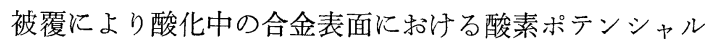
が低下することを示唆する。

（4）被覆試料について，酸化による質量増加が極め て少ない場合でも内部酸化は起こっている。

（5）加速酸化が起こらないかぎり $\mathrm{LaCrO}_{3}$ 被覆層 の外側には, 他の酸化物層は形成されない。

以上より, $\mathrm{LaCrO}_{3}$ 被覆は保護性の $\mathrm{Cr}_{2} \mathrm{O}_{3}$ 被膜に代。 て金属イオンの外方拡散に上る酸化を妨げるより安定な バリアーとして働くと考觉られる。

\section{謝辞}

GDS の測定をしていただいた日新製鋼株式会社に感 謝致します。

(Received April 20, 1990)

\section{文献}

1）例忘ば，谷口滋次：防食技術， 38，177 (1989); 永井 宏：金属学会会報, 21，973 (1982).

2) H. Konno: J. Electrochem. Soc., 134, 1034 (1987).

3）金野英隆，古市隆三郎：金属表面技術，39，29 (1988).

4）金野英隆, 北崎 聡, 常田昌広, 古市隆三郎：表 面技術，40，825 (1989).

5) D. B. Meadowcroft: Energy Conversion, 8, 185 (1968).

6）金野英隆，佐伯 功，古市隆三郎：防食技術， 37 , 338 (1988).

7）金野英隆，重国猛太，田村紘基，永山政一：防食 技術，34，670 (1985).

8）例光ば, 松本和順, 佐多敏之：黨業協会誌, 89, 26 (1981).

9) P. Kofstad: "High Temperature Corrosion," p. 418, Elsevier Applied Science (1988). 